\title{
Preliminary study on the consumption of mushrooms in Finland
}

\author{
MAIJA PEKKARINEN and HELVI MALIRANTA
}

\begin{abstract}
PEKKARINEN, M. \& MALIRANTA, H. 1978: Prel iminary study on the consumption of mushrooms in Finland. - Karstenla 18 (suppl.).

The aim of the study was to get preliminary information on the consumption of mushrooms by the Finnish familles. The study was carried out in 569 urban and rural households comprising 2312 persons in different parts of Finland in fall 1976 by using the interview method.

By results the gathering and the use of mushrooms differ to some extent in different parts of the country being most abundant in North and East Finland. Only a small part of mushrooms is gathered for marketing. Because of the scanty yield in 1976 only for a half of the households studied it was possible to gather mushrooms and for a half of them the amounts were under $5 \mathrm{~kg}$.

about 80 per cent of the family members mentioned eating mushrooms, adults more often than children, and females more often than males. The most known and used mushrooms were Lactarius, Boletus, Cantharellus and False morels. The most popular dishes were mushroom sauce, fried mushrooms, salad, stewed mushrooms, and mushrooms in force-meat. In addition, many other dishes were prepared but their use varied in different parts of the country.
\end{abstract}

M. Pekkarinen H. Maliranta, Department of Nutrition, University of Helsinki, SF-00710 Helsinki 71, Finland.

\section{Introduction}

Until now the use of mushrooms in the Finnish diet has not been investigated very much. In 1971 a household survey carried out by the Central statistical Office of Finland, included a study on the consumption of mushrooms, and the results showed that the average consumption in the whole country was as low as $0.7 \mathrm{~kg}$ per person a year. This study did not, however, provide data on the more detailed use of mushrooms. In 1976 the Academy of Finland accepted an extensive research project on fungi on its financing program, and a study on the consumption of mushrooms was started as an important part of this project. The study to be presented here is a preliminary one for the main consumption study which began in October 1977.

The aim of the consumption study is to obtain information on how much and what kinds of mushrooms are gathered and consumed by Finnish families, how they are used and how often, who in the families eat them, and whether are there any differences in the use of mushrooms in different parts of Finland. This information is necessary in the effort to increase the consumption of mushrooms and in trying to make the use of mushrooms more versatile than it is just now.

\section{Material}

The localities for the whole study were selected at random so that there were both urban and rural communities from all of the twelve administrative dis- tricts in Finland. From this sample 9 urban and 21 rural communities were taken for the preliminary study in the autumn of 1976, these localities covering the whole country. Seventy-five households were taken for the study in Helsinki, 25 in all other towns and $15-20$ in the rural communities. Acceptable data were received from 569 households, 29 per cent of them belonging to farmers and reindeer owners, 27 per cent to skilled labourers, 21 per cent to an office-holding class, and the last 23 per cent to different groups such as pensioners, independent enterprisers, students, etc. The size of the households varied from one to 13 members, the most common being a family of four or five persons. The total number of persons in the households studied was 2312,51 per cent of whom were females and 49 per cent males. The percentage of preschool children was about 7 , of children of school age 22, and of young people over 16 years of age 24 .

A little less than a half of the housewives worked outside the home in either whole-day or part-day work. Many housewives had some training in home economics and many of them were members of advisory organizations in home economics or of 4-H clubs. This fact may have affected the use of mushrooms in the diet, since most likely these housewives were more conscious mushrooms than those without any training in home economics.

Method

The preliminary study presented here was car- 
ried out in October-November 1976 by interviewing housewives at their homes. Some of the interviewers were trained mushroom advisers of the Finnish 4-H Union, others were advisers from two advisory organizations in home ecomonics, the Finnish-speaking and the Swedish-speaking Martha Organizations. Advisers of the last mentioned organization interviewed the housewives of the Swedish-speaking households.

\section{Results}

According to the results the picking of mushrooms varies in different parts of Finland (Table 1). On the average, 89 per cent of the households studied mentioned that they pick mushrooms for their own use and only 7.5 per cent pick for marketing. Table 1 shows that more families are picking mushrooms in North and East Finland and in Aland than in other parts of the country. The picking for marketing seems to be most common in North Karelia and in North Savo, where it surely means a welcome additional to the income of many families in poor circumstances.

$$
\text { Because of the scanty yields of mushrooms in }
$$
1976 due to unfavourable weather conditions the quantities picked were in general very small. About 45 per cent of the households did not pick mushrooms at all. More than half of those families that did pick mushrooms obtained a yield of less than 5 kilograms. About one third of the families had yields of 5 to 20 kllograms, and only 11 per cent picked more than 20 kilograms. The most popular mushrooms were Lactarius, Boletus, Canthareltus and false morels. The last mentioned is used most in Middle Finland, Lapland, Oulu and Mikkeli districts.
Table 1. Percentage of families in different districts who pick mushrooms

\begin{tabular}{lcc}
\hline District & For own use & For marketing \\
\hline Uusimaa & 76.0 & - \\
Kymenlaakso & 93.5 & 11.3 \\
Turku and Pori & 73.4 & - \\
Middle Finland & 88.2 & 11.8 \\
Häme & 80.0 & 3.3 \\
Vaasa & 88.5 & 7.7 \\
Mikkeli & 96.4 & 1.8 \\
Kuopio & 97.2 & 19.4 \\
North Karelia & 100.0 & 25.0 \\
Oulu & 94.3 & 5.7 \\
Lapland & 94.5 & 3.6 \\
Aland & 90.0 & - \\
\hline & 89.0 & 7.5 \\
\hline
\end{tabular}

Most people in Finland like mushrooms, according to this study 80 per cent on the average of the family members (Table 2). Some differences between the districts were observed, however. People in \&land are very fond of mushrooms, similarly the people in North Karelia, while the consumption of mushrooms was lowest in Turku and Pori districts. The use of mushrooms seems to depend to some extent on the age and sex (Table 3). Adults like mushrooms more than young people and children, women and young girls more than men and youngsters. In contrast, in the younger age groups more of the boys than girls liked mushrooms; however, the difference was not great.

Table 2. Percentage of family members who like mushrooms, and the use of mushrooms in households in different seasons

\begin{tabular}{lcccccr}
\hline \multirow{2}{*}{ District } & $\begin{array}{l}\text { Like mushrooms } \\
\text { \% of persons }\end{array}$ & \multicolumn{5}{c}{ Use, times a week } \\
\cline { 3 - 7 } & & I & II & III & IV & Average \\
\hline Uusimaa & 79.7 & 1.1 & 0.4 & 0.2 & 0.2 & 0.5 \\
Kymenlaakso & 82.9 & 0.7 & 0.5 & 0.3 & 0.2 & 0.4 \\
Turku and Pori & 65.7 & 0.6 & 0.4 & 0.5 & 0.2 & 0.4 \\
Middle Finland & 77.0 & 1.1 & 0.4 & 0.4 & 0.5 & 0.6 \\
Häme & 80.0 & 0.6 & 0.3 & 0.2 & 0.2 & 0.3 \\
Vaase & 77.5 & 1.0 & 0.5 & 0.4 & 0.2 & 0.5 \\
Mikkeli & 82.0 & 1.3 & 0.8 & 0.5 & 0.4 & 0.8 \\
Kuopio & 82.7 & 2.1 & 0.7 & 0.8 & 0.4 & 1.0 \\
North Karelia & 90.9 & 2.8 & 1.4 & 1.1 & 0.7 & 1.5 \\
Oulu & 83.1 & 2.1 & 0.7 & 0.5 & 0.4 & 0.9 \\
Lapland & 80.5 & 1.5 & 0.6 & 0.4 & 0.4 & 0.7 \\
Rland & 94.9 & 1.7 & 0.9 & 0.3 & 0.1 & 0.8 \\
\hline \multicolumn{1}{c}{ Average } & 79.6 & 1.4 & 0.6 & 0.5 & 0.3 & 0.7 \\
\hline
\end{tabular}

\footnotetext{
$I=J u l y$-September $\quad$ II = October-December

III = January-April $\quad$ IV = May-June
} 
Mushrooms are used in the diet most often during the best yield season, which is usually from July to the end of September. In the whole country the average use is 1.4 dishes of mushrooms a week, but more often in the districts of North Karelia, Kuopio and Oulu (Table 2). Mushrooms are used less in the winter, about once in two weeks, and still more seldom in late spring, on the average once in three weeks. Table 2 shows that mushrooms are used more often in North Karelia, Kuopio, Oulu and Mikkeli districts throughout the year than in other districts of the country.

The variety of mushroom dishes is not very great in Finland. The dishes most often prepared are mushroom sauce, fried mushrooms, salad with onion and sour cream, and stewed mushrooms. Sauce, salad and stewed mushrooms are usually made from Lactarius and mixed mushrooms, fried mushrooms from Cantharelzus and Boletus. The use of mushrooms as an ingredient in force-meat is also rather common in Finland with the exception of $\AA$ land, and the mushrooms used for this purpose are mostly Lactarius and mixed mushrooms. The use of the most common dishes varies to some extent between districts. Other dishes made from mushrooms include soups, baking and pot dishes, pies, pizzas and omelettes. Also their use varies between districts and some of them are quite unknown in the usual diet.

Conclusions

As a conclusion it can be said that this preliminary study does not perhaps give quite a correct picture of the consumption of mushrooms in Finland because of the low yield in 1976. Furthermore, the size of the sample studied was small and therefore the results are not valid for the whole of Finland in spite of the fact that the study covered the whole country. In any case the results are useful when comparisons are made between this study and the more extensive study carried out in the autumn of 1977 when the yield of mushrooms in the whole country was exceptionally good.

Table 3. Percentage of family members who eat mushrooms

\begin{tabular}{lccc}
\hline & & $\begin{array}{c}\text { Females } \\
\%\end{array}$ & $\begin{array}{c}\text { Males } \\
\%\end{array}$ \\
\hline Adults & & 93 & 89 \\
Children: over 16 years & 84 & 79 \\
& $7-16 "$ & 62 & 63 \\
& under 7 " & 51 & 55 \\
\hline
\end{tabular}

